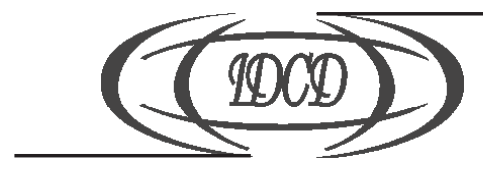

УДК $316.334 .2 ; 338.12$

\title{
I.П. МАКАРЕНКО,
}

канд. екон. наук, директор,

Інститут еволюційної економіки

02218, Україна, м. Київ, вул. Райдужна, 45

E-mail: makariee@gmail.com

\section{ЕВОЛЮЩЙНІ ПЕРЕДУМОВИ ВИНИКНЕННЯ ГОЛОДУ В ПЕРІОДИ СОЦІАЛЬНО-ЕКОНОМІЧНИХ КРИЗ}

Устатті визначено еволюційні передумови виникнення загроз настання масштабного голоду в перехідні періоди зміни технологічних укладів у національних економіках. Це, передусім, відставання у розвитку попереднього технологічного укладу, що спричиняє «слабкі смуги» зниження рівня випуску. Досліджено макроекономічні механізми формування і реалізації ризиків настання голоду за таких умов через зниження доходів домогосподарств (населення).

Ключові слова: економічна система, підсистеми, структура, економічна динаміка, технологічні уклади, інновації, Довгі хвилі Кондратьєва, системи цінностей, ризик настання голоду, економічна безпека, макроекономічні моделі, рівень автономного споживання.

Постановка проблеми. Причини та наслідки масштабного голоду в Україні та в регіонах Росії у XX ст. часто пов'язують із політичним чинником. Недостатнє вивчення його соціально-економічних передумов спричиняє ризик виникнення «раптових» економічних криз, пов’язаних із демографічними та гуманітарними аспектами. Проблема потребує системних досліджень.

Аналіз останніх досліджень і публікацій. У контексті економічної динаміки проблема досліджувалася фрагментарно. Зокрема, М. Кондратьєв (N. Kondratiev) [1] у «третій правильності» говорить про кризу в сільському господарстві, що виникає на початку Довгої хвилі. П. Сорокін (P. Sorokin) [2], досліджуючи цикли соціальної динаміки, звертав увагу на періоди напружень, що викликали революції та війни. Український дослідник В. Кузьменко (V. Kuzmenko) [3] описав періоди розширеннястиснення в рамках економічної динаміки.

Метою цієї статті є аналіз еволюційних механізмів виникнення ризиків економічних криз, виявлення ролі інновацій у подоланні протиріч економічного розвитку.

Виклад основного матеріалу. У процесі еволюції економічних систем час від часу виникають періоди так званих «слабких смуг» [4], коли загроза виникнення лихоліть стає найбільш вірогідною. В ці періоди має місце порушення макроекономічних балансів, спричинене економічними кризами, війнами, природними катаклізмами,

(C) MАКАРЕНКО І.П., 2014 
що дивним чином збігаються у часі. Це дає змогу певною мірою прогнозувати вірогідність їхнього виникнення. Настання голоду й інших гуманітарних катастроф поза періодами «слабких смуг» значно менш імовірне, навіть якщо їх провокувати навмисно (за інших рівних умов). Соціально-економічна система виявлятиме опір негативним факторам, маючи запас міцності, зокрема фінансової.

Для локалізації «місць» виникнення кризових загроз в економічній системі у контексті зростання імовірності голоду необхідно враховувати їі структурні особливості. Їх відображає макроекономічний метод декомпозиції економічної системи на підсистеми у форматі Системи національних рахунків (CHP). Він дає змогу підійти до вивчення економічних механізмів, що можуть викликати економічні кризи з негативними гуманітарними та демографічними наслідками.

У визначенні проблемних точок розвитку економічної системи неможливо не згадати про співіснування в ній двох протилежних систем суспільних цінностей, що входять у протиріччя. Їхня контроверсія може призводити до зміщення пріоритетів від захисту людської особистості (гуманітарного розвитку) як головної суспільної цінності, до розбудови економічної архітектури системи забезпечення суспільства матеріальними благами, що перебирає на себе роль основної цінності.

\section{1. Економічна система: модель «гуманітарні цінності-ієрархія»}

Будь-яку суспільну функцію неможливо реалізувати поза структурою економічної системи [5]. Тому водночас із функціональним аналізом здійснюється структурний аналіз. У нашому випадку структура підсистем економічної системи відображена у вигляді концентрованих кіл, що ілюструє їх вкладеність одна в одну - вищі у нижчі (рис. 1).

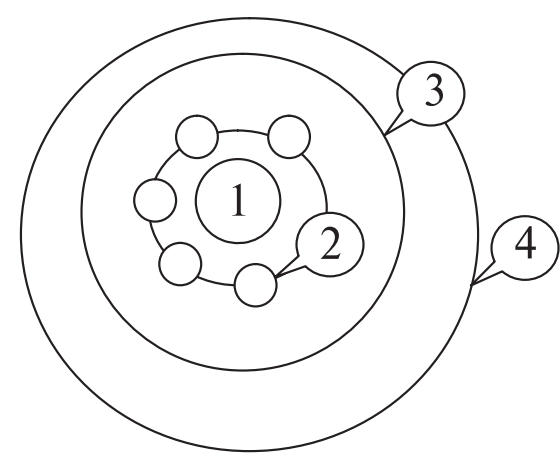

Рис. 1. Модель економічної системи як системи безпеки життєдіяльності Людини (акцент на гуманітарні цінності)

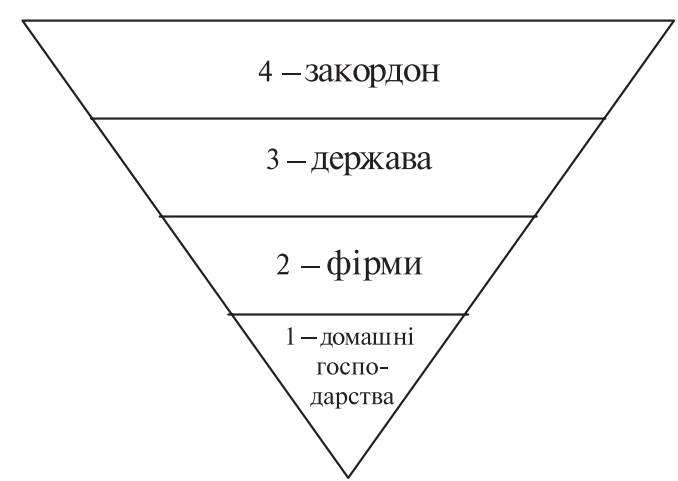

Рис. 2. Багаторівнева модель архітектури економічної системи (акцент на розбудову її структури, «ієрархії»)

(1) - економіка Людини, «домогосподарств» - перший рівень підсистем;

(2) - економіка фірм, «фінансових та нефінансових корпорацій» - другий рівень;

(3) - національна економіка, сектор «загальнодержавного управління» («держава») - системне макроекономічне середовище, що підтримує функціонування фірм та домашніх господарств у стабільних умовах існування - третій рівень підсистем;

(4) - «закордон», світова економіка (глобальна економіка за М. Кастельсом (M. Castells) [6]) - цілісна економічна система). 
Віднесення підсистем до категорій «нижчих» та «вищих» у межах економічної системи набуває змісту лише в разі конкретизації контексту. Наприклад, підсистема «Людина» (сектор «домогосподарства») може стати нижчою за підсистеми «Фірми» чи «Глобальна економіка» (сектор «Закордон») у разі нагальної потреби вдосконалення структури (ієрархії) економічної системи, якщо ефективність захисту життєдіяльності Людини з боку економіки значно знижується. Відповідно, суспільні цінності припустимо поділити на «гуманітарні» цінності та цінності «структури економічної системи» (скорочено - «ієрархії). Причому, хоч суспільна цінність Людини (населення) вища за цінність Глобальної економіки чи економіки взагалі (рис. 1), місце Глобальної економіки у ієрархії підсистем економічної системи вище за місце Людини (рис. 2).

Потреби виживання визначають вектор еволюції та завдання випередити конкурентів (інші економіки) у створенні найбільш ефективної соціально-економічної системи захисту Людини. Це вимагає мобілізації ресурсів для якісної розбудови ії якомога ефективнішої структури (ієрархії). Ресурси для розбудови цієї структури знаходять шляхом збільшення експлуатації природних ресурсів («землі») як основного фактора виробництва. Природні ресурси, перероблені працею (другим фактором виробництва), якщо вони цінні (в контексті безпеки життєдіяльності Людини), є капіталом - ще одним фактором виробництва. 3 цього виходить класична виробнича функція:

$$
Y=f(Z, K, L)(1)
$$

Вираз (1) не є функцією Кобба-Дугласа, яка є окремим випадком цієї функції у разі, якщо частки капіталу та праці у випуску продукції ( $Y$ ) дорівнюють одиниці $(\alpha+\beta=1)$. В реальності суми часток у цьому випуску можуть бути більшими або меншими одиниці. У класичній формі виробничої функції, явно враховано три фактори (земля $-Z$, капітал $-K$, праця $-L$ ), тому частка а включає капітал і землю.

Все це відбувається на тлі взаємодії протилежно орієнтованих систем цінностей, відображених на рис. 1 та 2. 3 одного боку, чим швидше і в більшій кількості мобілізовано ресурси, тим швидше буде створено ефективну структуру захисту Людини від ризиків (стабільної і безпечної життєдіяльності населення), на що власне й орієнтує система гуманітарних цінностей. Однак тут закладено протиріччя, оскільки чим більше результатів власної праці і ресурсів віддає у теперішній час населення на розбудову економічної структури, тим більше воно себе знедолює (відбувається виснаження підсистеми (1) на рис.1). Це відображає вираз:

$$
Y=C+S,(2)
$$

Де, у даному випадку: $Y$ - дохід кінцевого використання після всіх відрахувань, отриманий населенням від суспільно корисної праці, що розподіляється на поточне споживання $(C)$ та відкладене споживання, тобто заощадження $(S)$. Це пояснює кейнсіанську умову рівноваги економіки [7], згідно з якою загальнонаціональні заощадження $(S)$ мають дорівнювати загальнонаціональним інвестиціям (I). Вираз (2) також пояснює зміст рівноважної ринкової ставки відсотка (r), від якої залежать і заощадження $(S)$, і інвестиції $(I)$ :

$$
S=I(3)
$$

Уникнення гуманітарної катастрофи потребуватиме дотримання двох умов. Першою є обмеження на вилучення результатів праці у формі інвестицій $(I)$ на побудову системи (капітал $K$ ). Воно не має перевищувати рівня споживання $(C)$ у поточний момент взагалі (на макроекономічному рівні) та автономного споживання $\left(C_{0}\right)$ у 
критичних випадках (особливо на мікроекономічному рівні), що складно забезпечити. Другою - отримані від населення ресурси на розбудову економічної структури (результати праці) мають бути повернені у циклі кругообігу потоків капіталу якнайшвидше і в примноженому вигляді. Звідси випливає вимога появи інновацій, без яких таке примноження є вкрай проблематичним. Ця вимога відображена зміною параметрів виробничої функції (1), а саме введенням умови зростання віддачі від масштабу $(\alpha+\beta>1)$.

Подолання зазначеного протиріччя, що полягає у необхідності відкладеного попиту, тимчасового вилучення результатів праці та часткового «знедолення» населення, потребує збалансування економічного зростання та відповідної політики. Метод принципового вирішення цього завдання пропонували, зокрема, Р. Харрод (R. Harrod) та Є. Домар (Евсей Давидович Домашевицкий, англ. Evsey Domar) [8], однак найкраще це вдалося зробити P. Солоу (R. Solow) [8] в його моделі економічного зростання.

Тобто має бути дотриманий певний баланс між: капіталом $(K)$ та працею $(L)$, між споживанням $(C)$ та заощадженнями $(S)$, між заощадженнями $(S)$ та інвестиціями (I), за умови постійного удосконалення структури економіки (iєрархіï). Це висуває вимогу балансу і між пріоритетами протилежних систем суспільних цінностей - «гуманітарних» та «ієрархії.

\section{2. Взаємозв'язок між моделями «гуманітарні цінності» та «ієрархія»}

Відповідно до Системи національних рахунків національна економіка складається з чотирьох підсистем - сталих інституційних формувань - секторів економіки: «домогосподарств», «фірм» (сектор фінансових і нефінансових корпорацій), «держави» (сектор державного управління) та «закордону».

Впродовж еволюції економічних механізмів між ними утворилися функціональні та зворотні взаємозв'язки. Вони можуть реагувати не тільки на державний вплив, а й здійснювати взаємний вплив. Це важливо для пояснення причин того, чому в результаті, наприклад, порушення пропорцій у корпоративному секторі, виникає криза в секторі домашніх господарств чи в державному секторі.

Пропорції інституційних секторів економіки в межах національної економіки наближаються до так званого «Золотого перерізу» [9]: приблизно 30\% займають домашні господарства, 30\% - фірми (фінансові та не фінансові корпораціі), 30\% - сектор загальнодержавного управління, приблизно 10\% - інституційний сектор «закордон» [8]. Водночас ці пропорції є динамічними. Незважаючи на їх тяжіння до рівноважного стану, відображеного згаданими величинами, під впливом екзогенних факторів вони постійно змінюються. Наслідками таких змін стають кризи, обтяжені гуманітарними катастрофами залежно від глибини та тривалості впливу дестабілізуючого чинника. Війни як продовження гострої фази економічної кризи також часто завершуються глибокими руйнаціями економіки та гуманітарними катастрофами.

Зв’язок між моделями, поданими на рис. 1 та 2. може бути описаний основною тотожністю національних рахунків (4):

$$
Y=C+I+G+N E,(4)
$$

де: $Y$ - дохід усіх чотирьох інституційних секторів економіки - ВВП;

$C-$ споживання інституційного сектору «домогосподарства»; залежить від наявного доходу;

I - інвестиції фірм; залежить від наявного доходу та ставки відсотка; 
$G$ - споживання держави, залежить від державного бюджету та рішень парламенту;

$N E$ - споживання інституційного сектору «закордон», нетто експорт (експорт мінус імпорт); залежить від валютного курсу.

Споживання сектору «домогосподарства» $(C) €$ функцією наявного доходу $(Y-T)$, доходу $(Y)$ мінус податки $(T)$ :

$$
C=C(Y-T)
$$

Тобто будь-які податки, чи то на приватних осіб, чи то на фірми, чи то тарифи тощо - всі, в кінцевому підсумку, «сплачує» саме цей сектор. Оскільки будь-який податок, навіть на фірми, вкладається в ціну продукції й у вигляді доданої вартості передається по ланцюгу економічних взаємодій до кінцевого споживача, яким, по суті, є «домогосподарства».

Інвестиції фірм $(I) €$ функцією ставки відсотка $(r)$ :

$$
I=I(r) .(6.1)
$$

Лише великі фірми мають можливість здійснювати інвестиції за рахунок власного наявного доходу та капіталу. Це принципово для висвітлення причин переорієнтації потоків фінансів від малих фірм до великих й формування завдяки цьому інституту олігархізації економіки у разі зростання ставки відсотка (процентних витрат) до критичних значень і початку домінування наявного доходу $(Y-T)$ :

$$
I=I(Y-T)(6.2)
$$

Споживання сектору «закордон», нетто-експорт ( $N e-$ експорт мінус імпорт) $є$ функцією валютного курсу (e):

$$
\mathrm{Ne}=\mathrm{Ne}(e)(7.1)
$$

У секторі «закордон» також взаємодіють фірми, тому слід враховувати їхнє споживання залежно не тільки від валютного курсу, а й від наявного доходу $(Y-T)$ :

$$
\mathrm{Ne}=\mathrm{Ne}(Y-T)(7.2)
$$

Вираз (4) ілюструє також структуру сукупного попиту. Всі підсистеми національної економіки не можуть споживати більше ВВП, тобто - суми доходів в економіці (Y). Тому, якщо будь-яка підсистема (інституційний сектор) збільшує споживання, знайдеться інша підсистема, що вимушена буде зменшити споживання - виникають ефекти витіснення. У будь-якому разі це кінцевим підсумком відіб'ється на зменшенні споживання домогосподарствами. За відсутності інноваційних процесів це зменшення викличе кризові процеси, й рівновага між секторами відновиться, але на меншому рівні ВВП ( $)$. І лише інновація здатна відновлювати рівновагу між секторами економіки безкризово (за умови відповідної регуляторної політики держави).

Кожна з підсистем національної економіки споживає на рівні наявних доходів $(Y-T)$ плюс автономне споживання, тому вся національна економіка може бути відображена функцією споживання:

$$
C=C_{0}+C^{\prime}(Y-T),(8)
$$

де: $\mathrm{C}-$ споживання усіх чотирьох інституційних секторів економіки $(C+I+G+N E)$, тобто - ВВП;

$(Y-T)$ - наявний дохід (дохід $Y$ мінус податки $T)$;

$C_{0}$ - автономне споживання, у нашій інтерпретації - мінімально можливе споживання населенням (працюють люди чи ні, але кожного дня вони мають спожити як мінімум $C_{0}$ щоб не загинути);

$C^{\prime}$ - гранична схильність до споживання, параметр того, на скільки зміниться споживання, якщо дохід ( $Y$ ) зміниться на одну одиницю. 


\section{3. Механізми взаємовпливу підсистем у межсах економічної системи}

Наведені вище змінні у агрегованому вигляді задають основні канали трансмісії механізми взаємодії підсистем національної економічної системи. Ідентифікація аргументів та функцій цих змінних дає змогу визначити важелі управлінського впливу на зазначені підсистеми. 3'являється можливість дослідити причини і наслідки криз, обтяжених гуманітарними катастрофами.

Перший канал взаємовпливу пов'язує сектори «домогосподарства» (населення) та «держава». Він заданий виразом (5). Споживання залежить від наявного доходу. Податки, що зменшують наявні доходи домогосподарств, спрямовуються на забезпечення доходів сектору «загальнодержавного управління». Від цього потоку залежить споживання держави $(G)$ у виразі (4). Оптимальна величина цих податків - $30 \%$ від ВВП.

Другий канал поєднує сектори «домогосподарства» та «фірми» через заощадження $(S)$. Дохід, який залишився у «домогосподарств» після всіх відрахувань, розподіляється на поточне та відкладене споживання. Поточним споживанням $є$ таке, що у даний час здійснюють «домогосподарства», а відкладеним - заошадження. Заощадження населення є основним фінансовим ресурсом для інвестицій фірм.

Провідну роль у розбудові ієрархічної структури економічної системи відіграють «фірми» та «держава». Захист накопичених цінностей у цих секторах, особливо в кризові періоди «слабких смуг», може виснажувати сектор «домогосподарств» більше, ніж інші інституційні сектори економічної системи, що визначає точку виникнення загрози настання гуманітарної катастрофи.

Рис. 3 відображає модель взаємодії технологічних укладів [8]. Вона ілюструє відомі концепції С. Глазьєва (S. Glaz’ev) [10] та K. Перес (C. Perez) [11] про технологічні уклади (ТУ) та зміну технологічних парадигм. У період переходу до нового технологічного укладу $\left(T y_{2}\right)$ в результаті вичерпання потенційних можливостей попереднього технологічного укладу ( $\left(V_{1}\right)$ виникає зниження його реального рівня випуску $Y_{1}$ та відрив від реального природного (потенційно можливого) випуску $\bar{Y}_{p}(\mathrm{PПВ})^{1}[8]$. Рівень природного випуску нового технологічного укладу прямує до скорочення цього розриву $T Y_{2} \rightarrow Y_{2}$. За С. Глазьєвим, формування $T У_{2}$ триває приблизно 50-60 років, по завершенні чого виникає так званий перехідний період [11] із вірогідним падінням реального ВВП. Одним із таких періодів в економічній історії був період між світовими війнами.

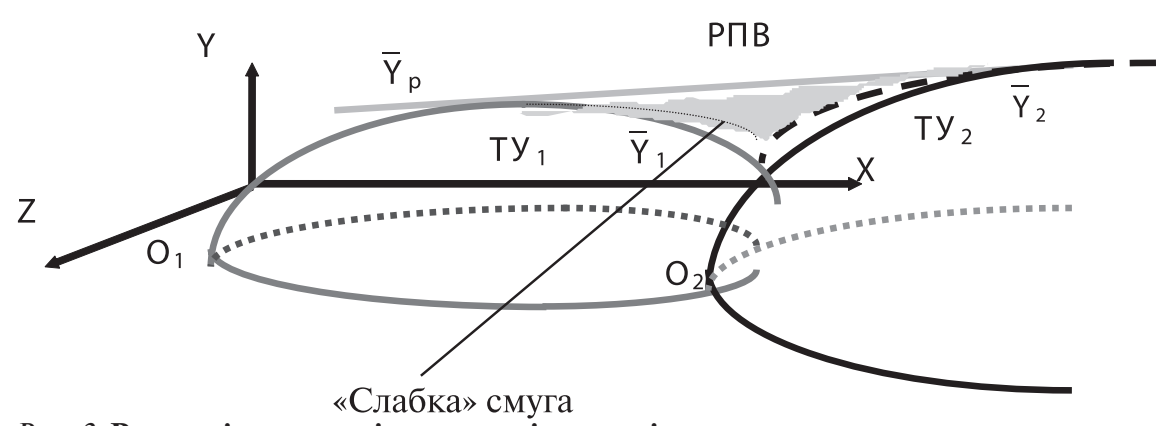

Рис. 3. Взаємодія технологічних укладів: механізм виникнення кризи

\footnotetext{
${ }^{1}$ Сформульовано у термінах класичної теорії.
} 
Важливо, що зазначені розриви рівнів випуску та «слабкі» смуги виникають у кінці або на початку формування технологічних укладів за умови відставання інноваційного розвитку економіки на попередніх етапах ії еволюції. I, навпаки, в разі високої динаміки інноваційних процесів, особливо інноваційних процесів розвитку $T У_{2}$, що спричинятиме зростання потенційного рівня випуску $\left(\bar{Y}_{2}\right)$, «слабка» смуга може й не відбутися. А якщо інноваційний розвиток на попередньому етапі $\left(T Y_{l}\right)$ був слабким, новий технологічний уклад $\left(T y_{2}\right)$ не встигає зміцнитися і підхопити динаміку. Тому результуючий випуск у перехідному періоді зменшується, запускаючи механізми економічної кризи. Зазначений розрив між рівнями випусків (заштрихована частина на рис. 3) фірми обох ТУ будуть намагатися компенсувати підвищенням цін.

Згідно з моделлю сукупної пропозиції, динаміка цін залежить від різниці рівнів природного і фактичного випуску:

$$
Y-Y=\alpha\left(P+P^{e}\right),(9)
$$

де: $(Y-\bar{Y})$ - відхилення фактичного рівня випуску $(Y)$ від природного $(\bar{Y})$;

$\left(P+P^{e}\right)$ - інфляційна складова, де $P^{e}-$ величина інфляційного приросту ціни;

$\alpha-$ коефіцієнт, що відображає кут нахилу кривої сукупної пропозиції.

У період еволюційної зміни $Т У$ відбувається згаданий вище розрив у рівнях випусків $\left(\bar{Y}_{1}\right.$ і $\bar{Y}_{2}$ від $\left.\bar{Y}_{p}\right)$. Згідно з моделлю сукупної пропозиції, це викликає зростання цін $\left(P^{e}\right)$. Реальний ВВП $(Y)$ у такому разі буде зменшений на величину інфляції $\left(P^{e}\right)$.

У разі настання розриву реальних рівнів випуску, падіння реального ВВП $(Y)$ відбувається за будь-яких умов. Наприклад, якщо Центральний банк рестриктивною політикою не допустить інфляцію, ВВП впаде через уповільнення ділової активності. 3 такої причини відбулося скорочення реального ВВП ( $Y$ ) в Україні на початку 1990-х рр. Тобто за будь-якого сценарію монетарної політики (інфляційного чи безінфляційного), у разі розриву рівнів випуску $(Y-\bar{Y})$, відбувається обвальне падіння реального ВВП (рис. 3), причому обмежувальна монетарна політика його прискорює через уповільнення ділової активності.

Подолання «слабкої смуги» кризи перехідного періоду вимагає прискорення розвитку нового ТУ, що потребує спрямування значних обсягів ресурсів для його розбудови у сектор «фірми». Аналогічна ситуація може скластися й після великих і тривалих війн. Тоді значна руйнація реального сектору економіки може призвести до тривалого падіння ВВП й відриву його від природного рівня $(Y-\bar{Y})$. Повоєнне відновлення промислового потенціалу також потребуватиме значних ресурсів.

Прискореної розбудови нового технологічного укладу або прискореного відновлення економіки після руйнівних війн вимагатимуть носії «ієрархічної» системи цінностей (рис. 2). Однак така діяльність викличе напруження на ринку ресурсів. Причому зниження рівня ВВП (вираз (4)) негативно відіб'ється на наявних доходах $(Y-T)$ усіх інституційних секторів економіки й спричинить зниження рівня споживання в економіці в цілому на величину падіння реального ВВП ( $Y$ ). Тому обмеження на ресурсному рівні відбудуться для всіх інституційних секторів економіки, але з огляду на особливу роль інституційного сектору «домогосподарства» у постачанні ресурсів для держави і економіки фірм (вираз (2), найбільше скорочення доходів відбудеться в секторі «домашні господарства».

Для «домогосподарств» основним ресурсом доходу є реальна заробітна плата. Оскільки ціна праці є категорією ринку праці, а проблема рівноваги - проблемою короткострокового періоду, класична модель відображає рівновагу на ринку праці в короткостроковому періоді. У довгостроковому періоді, згідно з класичними уявлен- 
нями, економіка наближається до рівноваги й повної зайнятості. Цей же процес без змін доходів населення може відбуватися лише за умови підвищення інновативності економіки.

На рис. 4 наведено модель рівноваги на ринку праці, яка, фактично, є класичною моделлю рівноваги національної економіки. У точці перетину кривих $L D$ (попиту) і $L S$ (пропозиції) попит на працю дорівнює пропозиції праці. Зниження реальної ціни праці $W / P$ і збільшення на цій основі зайнятості $L-$ це той вектор, у напрямі якого рухається економічна система, прямуючи до рівноваги.

Класична модель використана через те, що вона відображає центральну проблему, дослідженню якої присвячена наша стаття, а саме - закономірності та економічні механізми, що викликають обмеження ресурсів у економіці в цілому та, зокрема, в інституційному секторі «домогосподарства». Одним із важливих у зазначеному контексті парадоксів, що випливає з класичної моделі рівноваги, є «ефект необмеженої пропозиції праці».

За умови зниження реальної ціни праці ( $W / P)$ (рис. 4) точка перетину кривої попиту $L D$ з кривою пропозиції праці $L S$ буде зсуватися все нижче й лівіше, демонструючи зниження зацікавленості найнятих працівників продавати свою працю. Однак, як дослідив Т. Мальтус (T. Malthus), а за ним і Д. Рікардо (D. Ricardo), існує критична точка для зниження реальної ціни праці $(W / P)$, досягнення якої і подальше зниження $W / P$ призводять не до подальшого зниження пропозиції праці, а, навпаки, до різкого, стрибкоподібного, необмеженого зростання іiі пропозиції. Цією межею $є$ рівень доходів, що дорівнює рівню автономного споживання населення:

$$
W / P=C_{0}(10)
$$

За умови зниження реальної ціни праці $(W / P)$ до рівня, за якого сукупні доходи населення наблизились до мінімуму, який межує із критичним рівнем фізичного виживання $\left(C_{0}\right)$, у людей виникає прагнення одержати будь-яку роботу, незважаючи на принизливо низьку плату за неї. Описана ситуація ілюструє механізм запуску необмеженої пропозиції праці (рис. 4). Ця ж ситуація, закріплена в історичній пам'яті народу, може спричинити виникнення суспільного стереотипу надмірної покори населення.

Парадокс полягає в тому, що економіка, тяжіючи до рівноваги, досягає іiі, але суспільство несподівано отримує не добробут, а максимальну бідність.

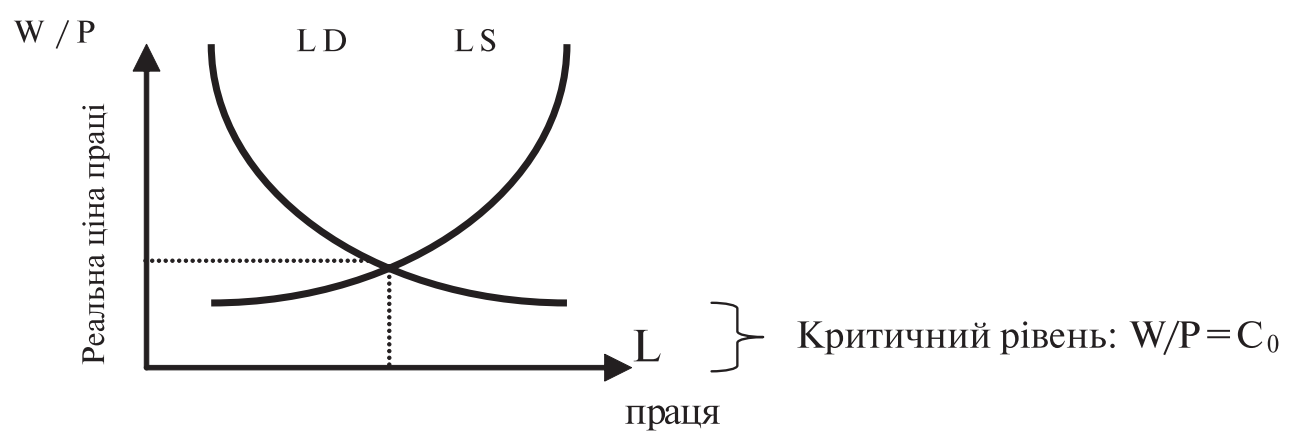

Рuc. 4. Класична модель рівноваги економіки. Рівновага на ринку праці 
Зрозуміло, що в народу, який перебуває на межі виживання, в умовах «слабкої смуги» виникає ризик настання гуманітарної катастрофи. Якщо в цих умовах здійснюється стратегія прискореного розвитку чи відновлення економіки після руйнівних війн, ці ризики можуть посилюватися. Їх спричинить ефект витіснення реальних доходів домашніх господарств у корпоративний сектор «фірм» через прискорену капіталізацію ресурсів у ньому. Реалізація зазначеного ефекту витіснення більш імовірна в неринкових умовах господарювання. В ринкових умовах із розвинутими фінансовими механізмами соціальних стабілізаторів ризики виникнення такого ефекту зменшуються, що є аргументом на користь фінансової системи як підсистеми безпеки. Приклади таких ситуацій відомі в довоєнні та повоєнні роки у СРСР (кількаразовий голод), а також в НДР («мармеладова революція»). Криза на пострадянському економічному просторі в 1990-ті рр. також може бути розглянута як такий приклад.

Із наведеного випливає, що передумови «слабких смуг» в Україні та в регіонах Росії у XX ст. були сформовані еволюційними механізмами розвитку економічних систем, зміною технологічних укладів. До головних причин їхнього виникнення можна віднести:

- значне відставання розвитку нового технологічного укладу, що зароджувався на початку XX ст., пригнічення всього попереднього розвитку економіки Російської імперіі;

- важкий перехідний період зміни технологічних укладів на початку XX ст., обтяжений двома руйнівними світовими війнами;

- слабка розвиненість (а може й повна їх відсутність) макроекономічних інститутів управління розвитком, що компенсувалася адміністративно-політичними важелями.

У контексті економічної безпеки функціонування інституційних секторів економіки, а також в контексті управління сталим економічним розвитком продовжують залишатися актуальними проблеми дослідження макроекономічних механізмів їхнього (інституційних секторів національної економіки) взаємного впливу.

Висновки: 1. Причини та наслідки масштабних голодувань в Україні та в Росії y XX ст. не можна пов'язувати лише із політичним чинником. Політичний чинник компенсував слабкість або відсутність макроекономічних інструментів.

2. Макроекономічне середовище має впорядковану структуру, кожна з їі підсистем виконує певну функцію і має конкретні канали впливу. Згідно з класифікацією Системи національних рахунків їх можна назвати: «домогосподарства» (канал впливу - наявний дохід), «фірми» (відсоткова ставка), «держава» (державний бюджет), «закордон» (валютний курс). Зниження доходів нижче рівня автономного споживання загострює ризики виживання для домогосподарств.

3. Система цінностей, закладена в структурі макроекономічного середовища, ставить на перше місце інтереси людини (домогосподарств), що задає критерій корисності підсистем та відносин. Система ієрархій, навпаки, ставить на перше місце побудову економіки. Протиріччя між цими різними контекстами однієї системи вирішується через динаміку розвитку, який забезпечують інновації.

4. Через затримку розвитку нового технологічного укладу зміни технологічних укладів можуть відбуватися на фоні тривалих періодів «слабких смуг». Вони спричинені провалами реальних рівнів випуску (ВВП), здатними викликати соціальноекономічні кризи, обтяжені гуманітарними катастрофами. 
5. Подолання цих проблем лежить у площині ефективного управління еволюційно неминучими змінами, тобто потребує адекватної інноваційної політики, розробка і реалізація якої неможлива без цілеспрямованих системних досліджень.

\section{ЛІТЕРАТУРА}

1. Кондратьев Н.Д. Большие циклы экономической конъюнктуры. Доклады и их обсуждение в Институте экономики / Н.Д. Кондратьев. - М., Ин-т экономики, 1928.

2. Сорокин П.А. Голод как фактор. Влияние голода на поведение людей, социальную организацию и общественную жизнь / П.А. Сорокин. - М.: Academia \& LVS, 2003. - 678 с.

3. Кузьменко В.П. Теория экономических циклов и глобальный финансовый кризис / В.П. Кузьменко. - К.: 2011. - Режим доступу: http://iee.org.ua/ru/publication/146/

4. Гринспен А. Эпоха потрясений. Проблемы и перспективы мировой финансовой системы / А. Гринспен. - Юнайтед Пресс: 2011. - 552 с.

5. Марков Ю.Г. Функциональный подход в современном научном познании/ Ю.Г. Марков. - Новосибирск.: Наука, 1982.

6. Кастельс М. Информационная эпоха: Экономика, общество и культура / М. Кастельс. - М., 2000.

7. Кейнс Дж. Общая теория занятости, процента и денег. // Кейнс Дж.М. Избранные произведения. - М.: Экономика, 1993. - С. 224-518.

8. Макаренко І.П. Макроекономічні умови формування та управління розвитком національних інноваційних систем / І.П. Макаренко. - Інститут еволюційної економіки. - К.: Інтертехнологія, 2009. - 320 с.

9. Крючкова I.В. Макроструктурні фактори розвитку економіки України та закон Золотого перерізу / І.В. Крючкова // Економіст. - 2005. - №9.

10. Глазьев С.Ю. Теория долгосрочного технико-экономического развития / С.Ю. Глазьєв. - М.: ВлаДар, 1993.

11. Perez Carlota. Change of Paradigm in Science \& Technology Policy. [Електронний ресурс]- Режим доступу: http://www.carlotaperez.org/papers/basic-changeofparadigminsci.htm\#archivo

Стаття надійшла до редакції журналу 10.09.2013

\section{REFERENCES}

1. Kondratiev, N.D. (1928). Bol'shie cikly ekonomicheskoj konjunktury. Doklady i ih obsuzhdenie v Institute jekonomiki [The Large cycles of the economic conjuncture. Lectures and their discussion in the Institute of economy]. M., In-t ekonomiki [in Russian].

2. Sorokin, P.A. (2003). Golod kak faktor. Vlijanie goloda na povedenie ljudej, social'nuju organizaciju i obshhestvennuju zhizn' [Famine as factor. Influence of famine on the people's behaviour, social organization and public life]. M.: Academia \& LVS [in Russian].

3. Kuzmenko, V.P. (2011) Teorija jekonomicheskih ciklov i global'nyj finansovyj krizis [Theory of economic cycles and global financial crisis] Kiev. Retrieved from http://iee.org.ua/ru/publication/146/ [in Russian].

4. Grinspen, A.(2011). Epoha potrjasenij. Problemy i perspektivy mirovoj finansovoj sistemy [Epoch of shocks. Problems and prospects of the world financial system].Yunayted Press [in Russian].

5. Markov, Yu.G. (1982) Funkcional'nyj podhod v sovremennom nauchnom poznanii [The Functional approach in modern scientific knowledge]. Novosibirsk: Nauka [in Russian].

6. Kastels, M. (2000). Informacionnaja epoha: Ekonomika, obshhestvo i kul'tura [Informacional epoch: economy, society and culture] M. [in Russian].

7. Keynes, J. (1993). Obshhaja teorija zanjatosti, procenta i deneg [General theory of employment, percent and money]. M.: Ekonomika [in Russian]. 
8. Makarenko, I.P. (2009). Makroekonomichni umovy formuvannia ta upravlinnia rozvytkom natsional'nykh innovatsijnykh system [Macroeconomic preconditions of national innovation systems forming and management]. K.: Intertechnologia [in Ukrainian].

9. Kriuchkova, I.V. (2005) Makrostrukturni faktory rozvytku ekonomiky Ukrainy ta zakon Zolotoho pererizu [Macrostructural factors of Ukraine economy development and the law of Gold cut] Ekonomist - Economist, 9 [in Ukrainian].

10. Glaziev, S.Yu. (1993). Teorija dolgosrochnogo tehniko-ekonomicheskogo razvitija [Theory of long-term technical and economical development]. M.: VlaDar [in Russian].

11. Perez, Carlota. Change of Paradigm in Science \& Technology Policy. Retrieved from http://www.carlotaperez.org/papers/basic-changeofparadigminsci.htm\#archivo

Стаття надійшла до редакції журналу 20.12.2013

\section{И.П. Макаренко,}

канд. экон. наук, директор, Институт эволюционной экономики,

02218, Украина, г. Киев, ул. Райдужна, 45

E-mail: makariee@gmail.com

\section{ЭВОЛЮЦИОННЫЕ ПРЕДПОСЫЛКИ ВОЗНИКНОВЕНИЯ ГОЛОДА В ПЕРИОДЫ СОЦИАЛЬНО-ЭКОНОМИЧЕСКИХ КРИЗИСОВ}

Причины и последствия масштабного голода в Украине и в регионах России в XX ст. часто связывают с влиянием политического фактора. Однако его возникновение имело фундаментальные социально-экономические предпосылки. Их недостаточная изученность способствует сохранению риска повторения «внезапных» кризисов, связанных с демографическими и социогуманитарными последствиями. Этим определяется актуальность изучения закономерностей возникновения гуманитарных катастроф. Упомянутые закономерности были рассмотрены нашими предшественниками в контексте социальной и экономической динамики Длинной волны Кондратьева в периоды напряженности, часто сопровождающейся революциями и войнами.

В рамках этого подхода нами выдвинута гипотеза, что на ранней стадии развития новых технологических укладов нарушается финансовый баланс ряда традиционных отраслей вследствие дефицита ресурсов, перераспределяемых на другие, инновационные направления, в частности на построение нового технологического уклада. Её подтверждение требует системного рассмотрения вопроса, что и определило цель настоящей статьи - анализ экономических механизмов возникновения риска наступления масштабного голода.

В основу анализа положена макроэкономическая методология рассмотрения экономической системы в контексте взаимосвязи её институциональных секторов (подсистем) в формате Системы национальных счетов (домохозяйства, фирмы, государство, мировая экономика). Рассмотрены макроэкономические модели их динамического взаимодействия. Выдвинута гипотеза отражения этого процесса динамикой альтернативных систем общественных ценностей (гуманитарной и иерархической), с учетом чего определены эволюционные предпосылки возникновения угрозы наступления голода в переходные периоды смены технологических укладов в национальных экономиках. Установлено, что ключевым фактором является отставание в развитии предыдущего технологического уклада, что обуславливает появление «слабых полос» в национальной экономике. Описан макроэкономический механизм возникновения риска наступления голода в таких условиях посредством снижения уровня доходов населения (домохозяйств) ниже уровня автономного потребления. Показано как слабость макроэкономических регуляторов компенсируется усиленным применением политических инструментов, что создает условия для деформации системы общественных ценностей.

Ключевые слова: экономическая система, подсистемы, структура, экономическая динамика, технологические уклады, инновации, Длинные волны Кондратьева, системы ценностей, риск возникновения голода, экономическая безопасность, макроэкономические модели, уровень автономного потребления. 


\section{I.P. Makarenko,}

Candidate of Economic Sciences (PhD), Director,

Place of employment: Institute of Evolutionary Economics,

02218, Ukraine, Kyev, Raiduzhna Str., 45

E-mail: makariee@gmail.com

\section{EVOLUTIONAL PRE-CONDITIONS OF FAMINE OCCURRENCE IN PERIODS OF SOCIO-ECONOMIC CRISES}

Reasons and consequences of large-scale famine in Ukraine and in the regions of Russia in the 20th century are often connected with the political factor. However its occurrence had fundamental socio-economic preconditions. Their insufficient studying facilitates conservation of risk of «sudden» economic crises related to demographic and socio-humanitarian consequences.

This determines the actuality of studying the regularity of occurrence of humanitarian catastrophes. The mentioned regularities were considered by our predecessors in the context of social and economic dynamics as agricultural and food crises arising at the beginning of the Kondratiev's Long Waves in periods of tensions, often accompanied by revolutions and wars.

Within the framework of this approach we presented a hypothesis that at the early development stage of the new technological modes the financial position of some traditional industries is violated through the deficit of resources, redistributed on other, innovative directions, in particular on the construction of the new technological mode. Confirmation of this hypothesis requires the non-fragmentary system consideration. It defined the purpose of the article - analysis of economic mechanisms of the risk of large-scale famine occurrence.

The basis of our analysis is grounded on the macroeconomic methodology of economic system consideration in the format of interconnection of its institutional sectors - subsystems set in SNA: households, firms, state, world economy. The macroeconomic models of their dynamic interaction are considered. The hypothesis of this process' reflection by the alternative systems of public values dynamic (humanitarian and hierarchical) is proposed.

The evolutionary pre-conditions of the large-scale famine occurrence in transitional periods of the technological modes replacement in national economies are determined. It is found that the key factor is the development lag of the previous technological mode. It preconditioned the appearance of «weak bars» of output level decline in a national economy.

The macroeconomic mechanism of occurrence and realization of large-scale famine risk is described in terms of population income level decline below the level of autonomous consumption. It is shown that the weakness of macroeconomic instruments is compensated by the increased application of political instruments. That creates essential precondition for the system of public values deformation.

Key words: economic system, subsystems, structure, economic dynamics, technological modes, innovation, Kondratiev's Long Waves, systems of values, risk of famine occurrence, economic security, macroeconomic models, level of autonomous consumption. 